\title{
SOCIAL POLICY AND LABOR MARKET DEVELOPMENT IN BULGARIAN TRANSITION PERIOD
}

\author{
Venelin Terziev \\ Academician of the Russian Academy of Natural History, Moscow, Russia, Prof. \\ D. Sc. (Ec.), D.Sc. (National Security), D.Sc. (Social Activities), Ph.D., National Military University, \\ Veliko Tarnovo, Bulgaria; University of Rousse, Rousse, Bulgaria, terziev@skmat.com
}

\begin{abstract}
The paper deals with the problems of social policy development on modern labor market presenting the example of the transition period in the Republic of Bulgaria. Social policy is characterized in its different aspects, as well as different approaches on employment and unemployment regarding labor force. The content of social policy and generalized value indicators for the standard of living of the population are discussed, as well as different stages in labor market and social policy development in the country outlining the most significant features. Conclusions are made about the functioning of labor market and the link to social and economic development.
\end{abstract}

Keywords: labor force, social policy, employment.

\section{INTRODUCTION}

The problems of modern labor market are subject to increasing interest in the field of research, policy discussions and management practice. They become especially topical in the years of transition and the membership of Bulgaria in the European Union, as well as the emerging new challenges facing Bulgaria in the new demographic, economic and social conditions.

The topical interest of the studied subject for the impact of various policies, programs and measures on the national labor market is conditioned by the fact that in recent years the implementation of specific programs and measures plays an increasing role in Bulgaria and is used as a main tool for the impact the labor market, both at regional and national level.

An important feature of the contemporary national projects of priority is their clear focus on the social field, i.e. on the person. The problems associated with investment in the person and improving the quality of life have never been paid so much attention before. The innovative approach to the habitual social sphere is the main difference of contemporary social, compared to all previously conducted projects at a national level. The effectiveness of the implementation of the social policy at any level (national, regional, corporate), dependents unconditionally on the financial capacity of those who planned it and implemented it (the state, municipality, company). The financing of a certain field depends directly on the solution of the problem 
related to the production development. It is namely this question that unveils the problems of formation of the revenue of the budgets, the deficit of finance and money, including for the implementation of the social policy as well. In case of lack of funds we cannot speak neither of the development of education, culture, health, nor of labor market and social protection of the population. All problems within the social sphere arise primarily due to lack of funds and are often associated with economic problems and errors in the formation of the expenditure of the budgets. By the way, the social policy itself and its basis - the socio-labor sphere, as evidenced by the practice, have a strong impact on the economic growth, financial flows and budgetary policy.

\section{SOCIAL POLICY CHARACTERIZATION}

When considering the social policy in a broader context, we can present some conventional and alternative modes of regulation of social relations in the field of labor:

- Regulation of social relations and issues concerning recruitment, release and immediate use of the labor of the working population;

- Regulation of social relations with regard to the nature and conditions of work and the possibilities of changing employment;

- Regulation of working time and leisure in terms of distribution and utilization between the different generations within the individual astronomical periods (day, week, year, human life). In all these directions, the occurrence of social problems is possible. These problems could be overcome or limited by the social policy, through its own means or by other scientific means (organizational, technical, sociological).

The problems regarding recruitment, release and immediate use of labor, that practically could be named as problems of employment and unemployment, shall be considered comprehensively and at several levels. Their macroeconomic aspect requires to strike a balance between demand and supply of labor in social scale, and the solution of the problem on implementation between the growth rates of unemployment and the rate of increase or decrease of inflation, to take into consideration the impact of the technical and technological upgrade as well as the restructuring of the economy on the number and structure of the unemployed. The classical prerequisite of market economy stands at the root of the problems of employment in macro-scale: the free and independent actions of producers in terms of production and investment.

The problems of employment and unemployment acquire new aspects in the context of globalization of the modern economy. In previous periods, the national economies could regulate the labor market through salaries and sanctioning of certain conditions of employment and dismissal, but today these regulators are insufficiently effective. The export of capital and production in countries where the labor force is cheaper and social costs lower, does not allow the use of the well-known mechanisms of regulation of labor and labor relations. Retraining and mobility, as well as higher education are not in any case the way out of unemployment in an open national economy. The competition among the active population is increasing and goes beyond the national borders and the national laws prove to be inappropriate to regulate the labor mobility.

Although interrelated to the problems at macro-level, the labor problems at the level employer - employee look different and draw the attention to another specific range of social problems. Problems related to the specific interests of both sides will inevitably emerge here as well.

According to Elmar Lange: «If you compare the interests of hired workers and those of the employers, you will easily find that, despite formal similarity they are essentially always in conflict - an improvement of the interests of one of the groups leads to deterioration of the interests of the other. This dependence applies primarily in respect to the interest in utilization of an increase of the income of employees, while maintaining the production of goods, it reduces the profit of the employer and vice versa... Thus in the field of industrial production both cooperation and conflict are structurally set».

Defining the interests of the employees in connection with recruitment and use of their workforce shows the following interests as typical:

- Interest in occupying a job position, which meets best the education degree, qualifications and skills. Seen from a different perspective, it comes to an interest in the fullest possible utilization of investment in education and vocational training funds;

- Interest in job security and humane working conditions;

- Interest in obtaining the highest possible price for the workforce provided. 
The supply of labor force depends on the degree of satisfaction of the specified interests, which are of equal importance for all. It is namely these common interests of the employees that make them join in professional associations, despite the actual competition between them in connection with employment.

The typical main interests of the employers are brought to:

- Recruiting of employees corresponding in number and qualification to the jobs available;

- Reducing as far as possible the cost of living labor;

- Autonomy in relation to product and labor markets.

The specified interests are common to all employers and make them teaming up with each other.

The social policy has a number of important features that can be classified by different characteristics (Table 1).

Table 1. Classification of the social policy

\begin{tabular}{|c|c|}
\hline Characteristics & Characteristics of the social policy \\
\hline $\begin{array}{l}\text { Level of development and implementation of the } \\
\text { social policy }\end{array}$ & $\begin{array}{c}\text { State social policy } \\
\text { Regional social policy } \\
\text { Public social policy } \\
\text { Social policy of the company, organization, } \\
\text { establishment }\end{array}$ \\
\hline $\begin{array}{c}\text { Contents of the activities, tasks of the social } \\
\text { policy }\end{array}$ & $\begin{array}{l}\text { Organizational, legal, social, economic, financial, } \\
\text { environmental, demographic, ideological, } \\
\text { propagandistic, socio-cultural }\end{array}$ \\
\hline Period of implementation of the social policy & $\begin{array}{l}\text { Long-term } \\
\text { Medium-term } \\
\text { Short-term } \\
\text { Current }\end{array}$ \\
\hline Efficiency - inefficiency & $\begin{array}{l}\text { Effective - effective, efficient, pragmatic, } \\
\text { implemented to a considerable extent, } \\
\text { comprehensible for the population } \\
\text { Ineffective - unreal, «on paper», unimplemented } \\
\text { to a considerable extent, incomprehensible to the } \\
\text { population }\end{array}$ \\
\hline
\end{tabular}

Policies on employment and unemployment follow different approaches in different countries. One of the approaches is brought primarily to the impact on the demand for labor force. The other approach is directed to the supply of labor force. In both cases, the practical solutions are directly or indirectly associated with the inflation growth. "That is why more and more economists in developed countries consider unemployment as a problem of the macroeconomic policy. The economic literature pays an increasing attention to macroeconomic policies for reduction of unemployment, such as policies on income taxes, taxes on payments, on exchange rate of the national currency, etc » (Terziev, 2013a).

There are also other opinions on that matter as well. French Professor Guy Sorman believes that the problems of employment and unemployment can be solved effectively and at the level of individual enterprises and companies without the direct intervention of the state: either through redistribution of labor or by downsizing the rate of the income growth in order to prevent future job losses, etc. In fact, a onedimensional policy on employment could not solve the problem, especially when it comes to mass unemployment. That is why the overall policy of each country in this sphere is a complex system of measures, which however stem in all cases from the understanding that the common level of employment can be increased only by an increase in the demand or through measures restricting the labor supply. The 
strategies to maintain employment through creation of conditions for flexibility and qualification of human resources, through encouraging employers not to cut, but to create new job positions, are extremely expensive and at the same time not so effective for the overall reduction of unemployment. Most developed countries pass on to new strategies aimed at changing the structure of the unemployed and targeting of measures primarily to persons, particularly threatened by unemployment. These are the so-called selective policies as opposed to the policies on more global targets (Terziev, 2013a).

The transition to selective policies of employment and unemployment is also dictated by the ongoing processes of segmentation and fragmentation of the labor market in recent years. According to those who support the theory of labor market segmentation in impaired perfect competition on the labor market, a primary and secondary market are formed, which are a prerequisite for the formation of different labor force groups with different situations in terms of their status in it. Fragmentation means that groups of people are formed who are in a more risky or disadvantaged situation on the labor market, fall out of it, or are relatively harder to be included again in labor relations. Starting point for the existence of such a phenomenon on the labor market is the impairment of the equality of the different groups in it, their inability to equal participation in this competitive market; unequal access of the different labor force groups in the ongoing labor market policies, etc.

The policies on employment and unemployment can be divided into active and passive. The active policies are those whose measures are aimed at employers and employees, either to maintain employment or for the restructuring and transformation of unemployment. The active policies in the field of labor and employment in particular aim at stimulating the labor market, creating conditions for bigger chances for people to fall in the labor sphere. The passive policies are those aimed at neutralizing the negative effects of job losses. They are directed to the effects of job losses and are expressed in ensuring the material welfare of the unemployed and their families.

\section{CONTENT OF SOCIAL POLICY}

The content of the social policy can be successfully introduced by an explanation of the main structural elements of the social policy and its operational concepts.

Social policy is to a certain extent a philosophy, ideology, program to impact on demographics, employment of the population, standard, lifestyle and quality of life of the population, its income level and structure of consumption of material and cultural wealth, pension and other forms of social security, social services of the population as well as provision of a targeted state aid to the most unprotected, vulnerable and poor parts of the population. This system also includes the measures aimed at creating conditions for self-defense in order to maintain and improve the level of well-being of their families. If the enterprises and companies have good prospects for their own development, they will be able to pay stable salaries, to keep jobs, to solve many other issues.

Today the social responsibility of business is widely discussed. Moreover, everybody has to define the meaning of this in their own way. Meanwhile, in other countries this is a concept that is understood by itself, inciting every entrepreneur to think not only about their own benefit but also about society in which they live and work. By "obligations of business» is also often understood additional social responsibility beyond the regular requirements. In a way - additional burden. Sometimes, however, this burden comes simply from financial, economic, investment objectives of some companies. In particular, from the concern about the territory on which the company operates. If the scope of activity of an enterprise (company) is related to the formation of a city or is of structural importance, it cannot go without sponsoring kindergartens, schools, hospitals etc. Municipalities do not have sufficient funds to support this infrastructure, and the enterprises, which employ the residents of a town/village, cannot leave people to the mercy of fate. Alone, without the help of their enterprises, they will not be able to provide education for their children, to receive medical help, etc. and the enterprises have no choice but to invest money in this social infrastructure.

As we know, today there is a deficit of labor force everywhere. At the same time, the companies need to cut actively "harmful», low-paid unskilled jobs. Moreover, they themselves train qualified specialists for new jobs, deal with the system for vocational training and retraining.

Social security is a comprehensive system of economic, legal and social rights and freedoms regulated by laws; social guarantees for citizens, providing the population with guaranteed level of security and life activity. Under the conditions of transition to a market economy, as well as after this period, it is of essential importance to establish the rights and social guarantees within the population employment field, the protection of vulnerable groups and their provision with an income not lower than the corresponding subsistence minimum, the prevention of decrease of the actual standard of living (real income of the population) in relation to price increase. 
Social protection is a system of priorities and mechanisms for implementation of establishment of social, legal and economic guarantees for citizens in the legislation; a system of management bodies of other institutions at all levels, as well as a system of social services that provide a certain level of social protection, reaching a socially acceptable standard of living for the population in accordance with the specific conditions of social development. The system of social protection of the population, created in Bulgaria, includes measures aimed at establishing a minimum level of remunerations, pensions and scholarships; introduction of a national system of aid for children, support for large families, differentiation in the level of remuneration of different categories of workers in the budgetary sphere etc.

Social support is a system of measures to assist certain groups of able-bodied citizens who are temporarily in a difficult economic situation (partially or entirely unemployed, young people, etc.), by providing the necessary information, funds, loans, training and retraining, legal protection and implementation of other privileges.

Social self-protection of population is the development of entrepreneurial and employment initiative, increasing the activity of the citizens and their organizations to improve the conditions of life.

Social assistance is a system of measures to help individual persons or groups who are actually in need to overcome or mitigate the difficulties of life, to maintain their social status and complete life activity, to adapt to society.

The main types and forms of social assistance are established at local (municipal) level, taking into account the economic circumstances and the factor of social need of the citizens. They include:

- Financial aid: one-off aid; aid for payment of transport services; assistance in extreme situations which resulted in large one-off losses (fire, flood, etc.);

- Social security benefits in natural form: providing necessities (food, shoes, clothes, etc.); repairs of homes, vehicles; distribution of drugs; provision of free food; provision of fuel;

- Humanitarian aid;

- Services and privileges: sending to rehabilitation centers, social and psychological assistance centers, homes and accommodation centers, etc.;

- Legal aid (protection of rights and interests, defense in court, etc.);

- Psychological support;

- Professional orientation (vocational rehabilitation assistance, advice on career choice);

- Information support, etc.

The basic principles of social assistance are: addressing, security, differentiated approach in determining the citizens in need, the size and type of aid, complexity, social reaction - review of social norms with respect to increasing the standard of living, independence of territorial authorities in determining the forms and levels of social assistance, as well as the determining the categories of citizens who need this assistance.

Criteria for providing social assistance could be:

- The combined family income or average income of a person which is lower than the sum of the established subsistence minimum at national level for each family member by socio-demographic groups or equal to the relevant amount of the established subsistence minimum (lower than the minimum monthly wage, minimum pension, etc.);

- Lack of means of subsistence; loneliness and inability for self-service;

- Material damages or physical damages that resulted from natural disasters, catastrophes, national conflicts, as well as performance of official duties, etc.

Based on these criteria a database is created in the different municipalities and administrative districts comprising information on persons in need of targeted aid - a file that contains detailed information for citizens in need.

Social development is a process of change in society, expressed in changes in its structure, including the major classes, groups, layers, and social relations, i.e. changes in relationships between people as representatives of social groups in respect to their social status, their way of life.

Social norm is scientifically justified, calculated value or parameter setting the quantitative measure or level 
of development of the social process.

Way of life is a particular system of sustainable and reiterating forms of life activity and the methods of their organization, which have an internal unity.

Quality of life characterizes the quality aspect of meeting the material and cultural needs of the people by comparing their actual level with the selected standard of living.

Standard of living - this is to provide the population with the necessary for life material, spiritual, cultural and social consumer goods and the degree of satisfaction of the people with these goods. Along with the quality of life, the standard of living is among the most important conditions for the lifestyle. The standard of living is expressed in the quantity and quality of the consumed by a person commodities and services, starting from the "primary» that meet the needs of food, housing, clothing, means of transport, means to maintain health, etc., and reaching to the most complex, «high» needs related to satisfaction of spiritual, moral, aesthetic aspirations. The term "standard of living" is broader than such indicators as income growth and production of consumer goods.

Socio-demographic indicators of the standard of living: fertility, mortality, population growth, average life expectancy, expected life expectancy, etc.; indicators characterizing the condition and protection of the environment; indicators and standards for social services and social security of the population.

\section{GENERALIZED VALUE INDICATORS FOR THE STANDARD OF LIVING OF THE POPULATION}

Solvent demand by the population - demand for material goods and services, secured by finances. The volume and structure of the solvent demand are determined by the volume of cash incomes of the population and received loans, from which the mandatory payments (taxes, repayment of loans, insurance, etc.) are deducted; by their distribution among the different groups of the population in accordance with the social, professional and demographic structure of society; by the level of education and culture of the population; by the level of retail prices and service charges, as well as by their correlation with other factors.

Needs of the population - a combination of material needs (food, housing, household items, etc.), cultural, spiritual and social needs (education, meeting of cultural needs, leisure needs, etc.), vital goods which need to be met.

Real income (excluding services) - part of the national income, used by the population to meet its material, cultural and spiritual needs.

Real income (including services) - part of the gross national product used by the population for consumption and accumulation of material goods and services.

In order to characterize the increase (decrease) in the real income, indexes of real income of the population are calculated, as well as indexes of real income in terms of social groups.

Incomes of the population - the amount of funds received by the population from different sources, in the form of cash and natural receipts, free services and discounted services (in the unpaid part of them).

Cash household income - this is the sum of cash in the household in the form of salaries, pensions, scholarships, benefits, entrepreneurial income, interest, dividends and other income from property, real estate, stocks and bonds, funds from the sale of products from personal subsidiary economy.

Aggregate income - in statistical practice, this is one of the main indicators of standard of living for the material security of the population and includes all types of cash income. It also includes the value of the natural proceeds received from the personal subsidiary economy and used for private (domestic) consumption.

Both cash and aggregate income can be total - to the payment of taxes and mandatory payments (gross), and disposable - after the said payments (net). Disposable income is the maximum amount of money that a household can spend on final consumption of goods and services without using savings and other sources.

Average income per household member - aggregate household income (salaries, pensions, scholarships, benefits, income from entrepreneurial activity and personal subsidiary economy, income from other sources), calculated for a month or a year for each household member. When calculating the average income per household member citizens that live together are taken into account and ablebodied unemployed members who are not registered in labor offices, as well as children and adolescents who are fully insured by the state, are excluded. 
Minimum consumer budget - a range of consumer goods and services in natural and value form that meets the requirements of the relevant science-based standards and regulations and is officially recognized by the public as acceptable at the present stage of its economic development.

Minimum consumer budget (budget of the consumer minimum) - it is expressed in a value assessment of consumer goods and services to satisfy basic physiological and socio-cultural needs of workers and their families at a level of development of the country.

Subsistence minimum - a socio-economic category, characterizing the combination of the minimum volume of material goods and services in a given ratio, necessary and sufficient to secure the health and maintenance of vital activity of the employed person and their family, to reimburse lost labor force and to secure continuation of the family.

Index of the impact of prices on the limits of subsistence minimums - a relative indicator, characterizing changes in the limits of the subsistence minimum during the current and base period.

Social layers - social communities, distinguished in society by one or several related qualities of its differentiation: income, prestige, level of education, culture, residence, participation in the exercise of power, etc. Many of the social layers are formed at the intersection of different types of structures: socioprofessional, qualification, educational, etc.

Middle layers - classes and social groups occupying an intermediate position between the two poles in society.

Social structure of society - the relationship between the social groups. Types of social structures: sociodemographic, socio-professional, national-ethnic.

Socio-demographic structure is the relationship between elements such as gender, age, marital status.

Socio-professional structure unites people by professional characteristics and by occupied position professions associated with highly qualified, creative and intellectual work, etc.

Social class structure - distinguishes classes and social groups by the following criteria: relation to the means of production; role in the social organization of labor; amount and source of the received part of the public wealth.

National-ethnic structure - relationship between nations, nationalities, clans, tribes, national and ethnic groups.

Social stratification - structuring of inequality between different social groups.

Social guarantees - conditions and means of providing the citizens with the opportunity to use their state given by law socio-economic, political and personal civil rights and freedoms. The reliability of the social guarantees determines the degree of implementation of the rights and freedoms provided. The main law of the state (the Constitution) and regulations indicate the specific mechanisms for actual implementation of social guarantees.

Social priorities - social tasks, which are recognized by society at a given stage of its development as urgent, requiring a decision of major importance.

Level of low security (poverty line) - cash income amount needed to cover the cost of acquiring the consumer goods and services, necessary for the individual and their family. It is measured using the subsistence minimum or other indicators (minimum wage, etc.).

Social rehabilitation - this is a process aimed at recovering of social life activity of the individual, which has been limited by age or due to other reasons.

Social security - a system established by the state to secure the citizens in case of retirement, full or partial disability, loss of a person who supports the family, as well as benefits for large and poor families.

Unemployed - an able-bodied citizen, who has no income from work or other legitimate source due to reasons beyond their control, registered in the employment office, looking for work, willing and ready to work, and ready to finish a training course if necessary.

Temporary unemployment benefits - a state compensation to citizens under certain conditions: loss of work in enterprises, institutions and organizations, as well as for those who seek to begin work again after a long break.

Public paid job - activities organized by the authorities for providing temporary employment of citizens who 
have lost their jobs and are looking for work, primarily from socially unprotected groups.

Labor market - a sphere of socio-economic and legal relations created in connection with the demand and supply of labor force, when connecting the personal and material factors of labor.

Refugees - persons with different nationalities, who have entered or are willing to enter the territory of another country.

Homeless - a person without a certain place of residence and profession.

To summarize, we can draw the conclusion that the content of the social policy is a program of specific actions of public authorities and non-state institutions, public associations in the implementation of tactical and strategic tasks aiming at harmonization of the public relations.

\section{SOCIAL POLICY DEVELOPMENT}

In the years of transition to a market economy and difficulties of companies in relation to increasing competition, some specific interests of the employers which contradict strongly to the interests of the employees come to the fore. Such are the interests of the conclusion of fixed-term contracts, even when the nature of the labor relations suggests permanent contracts. The demands of the employers also include greater freedom in the lay-off of employees for economic reasons. This requires changes in the labor legislation (e.g. the adoption of a new Labor Code), to reflect the new circumstances and to protect adequately the interests of the employees and to provide greater economic freedom of the employers at the same time.

The interests and respectively the problems related to them between citizens and society in general take an important place with regard to the division of labor. The aspects are at least two: the access of all active citizens willing to work to the competitive struggle for jobs and the opportunities for the redistribution of working time and leisure between generations and only between the working population in a way that increases the chances of all people willing to work, to exercise some kind of paid work which is useful for society.

Ralf Dahrendorf says: «In any case a new line between those who have secure, well-paid and obviously meaningful job, and those for whom this does not apply begins to form». A new policy is necessary, which according to Dahrendorf aims: "While active society still determine the conditions of life and self-esteem of the people, to open the way to those who are in risk of falling into the lower classes, the way to the labor market, without turning them into working poor people who do have a job, but cannot improve their living standards. This sounds the same as trying to square the circle, but is not so, if we assume the idea of a redistribution of labor. More flexible working conditions, various forms of employment contracts as well as overtime hours reduction are necessary. Such measures distress the wealthy people in the active society, but are inevitable for the cohesion of the societies» (Terziev, 2013a)

Now strategies for socio-economic development are being developed for following longer periods. The social policy has changed radically its instruments due to the development of a legislative base oriented towards joint activities of government and business. Thus the essence of the social policy is expressed in its strategy and tactics in the activities of the state directed towards satisfaction of material and cultural needs of society, towards provision of necessary assistance primarily to those who need it most, feasible on the basis of the principles of justice and identification of recipients.

Undoubtedly, social policy and social-labor sphere are in a constant process of development. Moreover, social policy requires substantial financial resources and has a strong impact on the development of the national economy, economic growth, the dynamics of gross domestic product (GDP), the movement of society and progress. It is obvious that without a well-developed system of education, culture, health, etc., the development of production is impossible, as it is namely these factors that have a huge impact on people as the main (personal) factor of production. As an example of the opposite influence of social policy and sociallabor sphere on the economy, we can consider the functioning of the pension system. The state and employers spend huge resources for development and implementation of the pension system. On the one hand, this can be regarded as a purely social measure, which is not related to economic indicators: the pensioner does not work, does not produce output, does not participate in the creation of the GDP, etc. On the other hand, if the pension system is created from the perspective of social justice, if the amount of the pension depends directly on the performance and quality of work of the pensioner in the past, this system will also encourage the labor productivity and the production development as a whole. Similar interconnection exists between the economic efficiency and the solution of the employment problem, labor protection, social security, development of culture, health, science and education. 
We can distinguish several stages in the development of social policy:

First stage - sharp contraction of the social policy (early and mid-90-s ) - the maximum contraction of nonprofile assets is accepted by companies with different forms of property as a condition for the survival of the company. Two-thirds of the objects of social infrastructure are transferred to the municipalities, as this has all the elements of spontaneity and not high degree of control.

Second stage - stabilization of the social infrastructure (1997/1998-2000) - the approach to social objects becomes more differentiated.

Third stage - economic upturn (transition of enterprises from stage of survival to stage of development) optimization of the social infrastructure.

Today, an optimization of social infrastructure can be achieved primarily at the enterprise level. In the first place, because at a micro level, the social problems occur most acute (employees' needs for housing, medical services, the relevant cultural and educational environment, etc.). In the second place, the company is interested that its employees are healthy, able-bodied, educated. In the third place, each company in a market economy aims at gaining profit, which may not always be in the form of money (but in status, in obtaining credit of trust by the public, by the local administration, that allows it to fully implement its strategic objectives, both commercial and non-commercial). Thus the economy and social policy are organically connected, which requires regular and moderate choice of priorities for their coordinated development both at national and regional and local level.

Social policy in the field of labor means a combination of methods, tools and institutions to regulate social relations in connection with the division of labor on the public scale, as well as in relation to targeting, recruitment, release and direct participation of people in the labor process.

The social nature of the labor policy has as an object the relatively autonomous personality participating in «the relations with respect to labor», and the specific labor relations in accordance with their own interests, abilities and features, differently adaptive to specific conditions of work and social life. The person, the personality appears as a special object of sociopolitical activity and at the same time is present in social life as a free subject, owing personal workforce and making independent decisions on how to exercise its ability to work. In all societies, any action of the subject of policy (state, community, enterprise, etc.) depends on the interaction with the person and of their voluntary participation in labor relations and relations with respect to labor.

The first feature of the social policy in the field of labor is that it shall be based on the dual position of the person - as an object and as a subject of sociopolitical impacts.

The second feature comes from the fact that the individual is both subject of labor and social relations and as such, the individual owns both labor and civil status.

The social policy has a complex task to coordinate the interests of the person as a citizen and employee, as a citizen and employer, those of the employee and the employer with those of society as a whole. In general, this means that the interests of the able-bodied persons shall be coordinated with the interests of the employers and the needs and interests of society.

The third feature lies in its direct connection and interaction with the social structure of society. Through preparation, career guidance and directing people to work in one sector or another, the social policy defines substantially the social structure. The processes of transition and change in the employment and social situation are related to the occurrence of problems and costs. The task of the social policy is to minimize personal losses and facilitate the transition to a more progressive structure of society.

The fourth feature lies in the strong influence by the development of demographic processes. The positive or negative development of the demographic processes affects the sociopolitical decisions on employment, unemployment, social security and assistance.

The fifth feature is related to its connection with the economic and political situation. All economic crises and structural changes in the economy that may also occur as a result of purely political decisions, impact directly the employment of the population, the level of salaries and social benefits. The aim of the policy is to mitigate the severity of the problems associated with the gap between demand and supply of labor force, between the necessary resources of subsistence and the amount of salaries and social benefits.

In the period of the transition and up to now the policy in the labor market in Bulgaria has reflected the needs of the economy to varying degrees. In 1990-2000 this policy was built together with the development of the labor market and therefore its nature was primarily preventive. Since 2000 the policy on the labor market 
included more active programs and activities so that it can reflect more adequately the changes in the macroeconomic environment and the periods in the economic development. As a whole, however, the active policy had a minor and temporary role in supporting employment and could not replace the investment activity for the creation of jobs. The economic development has been crucial for the demand and supply in the labor market and its balance in the different periods of the development.

The anti-crisis policy in Bulgaria in the period from 2008 to now has mainly been focused on financial stability and consolidation and has severely limited the support for employment. A specific short-term policy was pursued for the protection of the labor market through programs for reduced working hours and for business support but this had a temporary effect and was not supported by other effective measures for employment creation and for sustainable turn in the unemployment growth (Terziev, 2018a-g; Bogdanova, 2018h; Bogdanova, 2017a; Bogdanova, 2016a; Bogdanova, 2015a; Bogdanova, 2011a; Terziev, Banabakova, Georgiev, 2018i-k).

\section{CONCLUSION}

The strategic objective of the employment policy is to achieve full and productive employment of the people capable and willing to work. The targets and the specific tasks for the realization of this goal are related to the development of the economy and the population, the achievement of a perfect match between the demand and supply of labor, the creation of job opportunities for all willing to work and for enterprises - to increase their competitiveness and efficiency.

The consideration of the features of the economic development and the possible impacts on the labor market gradually become an inseparable part of the process of policy making in the labor market. In the early periods of the development of the labor market, the policies regarding it are primarily aimed at tackling the effects of the economic reforms on employment, but now the policy of the labor market has a clearly active character and is aimed at influencing the processes or the behavior formation among the target groups according to planned purposes. The functioning labor market in the country is an adequate mechanism of the market environment and the pursued policy is increasingly based on the existing relations and interactions between the periods of development of the economy and the labor market.

In the recent years of transition, within the development of the labor market, the policy has been focused on more active actions aiming at supporting the restructuring of the workforce and the increasing of its mobility. The predictability of the economic processes and of the effects on employment is not high and still remains within the short-term events and does not have a long-term character. The development of models to predict the needs of the workforce is imperative for the establishment of a closer link between the policy in the labor market and the periodicity in the dynamics of the economy (Terziev, Arabska, 2014a).

\section{REFERENCE LIST}

Terziev, V., Arabska, E. (2014a). Assessment of active social policies' impacts on labor market in the Republic of Bulgaria // Sotsialyno-ekonomicheskie i pravovay razvitiyaekonomiki: kolektivnaya monografiya. - Ufa: Aeterna, 2014. - ISBN 978-5-906769-97-8 (Terziev, V., Arabska, E. Assessment of active social policies' impacts on labor market in the Republic of Bulgaria // Социальноэкономические и правовы развитияэкономики: колективная монография. - Уфа: Аэтерна, 2014. - ISBN 978-5-906769-97-8).

Terziev, Venelin. (2013a). Vazdeystvie na politikite na pazara na truda za osiguryavane na zaetost: monografiya / Universitetski izdatelski tsentar pri Rusenski universitet "Angel Kanchev". - Izdatelstvo «Dema pres-Ruse», 2013. - ISBN 978-954-92964-2-6 (Terziev, Venelin. Въздействие на политиките на пазара на труда за осигуряване на заетост: монография / Университетски издателски център при Русенски университет "Ангел Кънчев". - Издателство «Дема прес-Русе», 2013. - ISBN 978-954-92964-2-6).

Terziev, Venelin. (2018a). Importance of human resources to social development. // ADVED 2018-4th International Conference on Advances in Education and Social Sciences Abstracts \& Proceedings, 1517 October 2018- Istanbul, Turkey, International Organization Center of Academic Research, www.ocerints.org, Istanbul, Turkey, 2018, pp. 204-212, ISBN: 978-605-82433-4-7. 
IJASOS- International E-Journal of Advances in Social Sciences, Vol. V, Issue 13, April 2019

Terziev, Venelin. (2018b). The active model of a social programme and its strategic advantage. // ADVED 2018- 4th International Conference on Advances in Education and Social Sciences Abstracts \& Proceedings, 15-17 October 2018- Istanbul, Turkey, International Organization Center of Academic Research, www.ocerints.org, Istanbul, Turkey, 2018, pp. 189-203, ISBN: 978-605-82433-4-7.

Terziev, Venelin. (2018c). Active social programs development in Bulgaria: contemporary challenges and social management instruments. // ADVED 2018- 4th International Conference on Advances in Education and Social Sciences Abstracts \& Proceedings, 15-17 October 2018- Istanbul, Turkey, International Organization Center of Academic Research, www.ocerints.org, Istanbul, Turkey, 2018, pp. 149-163, ISBN: 978-605-82433-4-7.

Terziev, Venelin. (2018d). Social assistance services and integrated employment in Bulgaria. // ADVED 2018- 4th International Conference on Advances in Education and Social Sciences Abstracts \& Proceedings, 15-17 October 2018- Istanbul, Turkey, International Organization Center of Academic Research, www.ocerints.org, Istanbul, Turkey, 2018, pp. 164-177, ISBN: 978-605-82433-4-7.

Terziev, Venelin. (2018e). Impact of the labor market policies for ensuring employment. // ADVED 2018-4th International Conference on Advances in Education and Social Sciences Abstracts \& Proceedings, 1517 October 2018- Istanbul, Turkey, International Organization Center of Academic Research, www.ocerints.org, Istanbul, Turkey, 2018, pp. 178-188, ISBN: 978-605-82433-4-7.

Terziev, Venelin. (2018f). Development of social policy as theory and practice in Bulgaria. // 3rd Central \& Eastern European LUMEN International Conference, New Approaches in Social and Humanistic Sciences NASHS 2017, Chisinau, Republic of Moldova, June 8-10, 2017, 2018, pp.493-504, ISSN (print): 2601 - 2510, ISSN (on-line): 2601 - 2529, ISSN-L: 2601 - 2510, ISBN: 978-1-910129-15-9.

Terziev, Venelin. (2018g). Modeling active social programs in Bulgaria through social entrepreneurship encouragement. // 3rd Central \& Eastern European LUMEN International Conference, New Approaches in Social and Humanistic Sciences NASHS 2017, Chisinau, Republic of Moldova, June 810, 2017, 2018, pp.505-516, ISSN (print): 2601 - 2510, ISSN (on-line): 2601 - 2529, ISSN-L: 2601 2510, ISBN: 978-1-910129-15-9.

Bogdanova, Margarita. (2018h). Policies and Instruments for Social Development. // Journal of Innovations and Sustainability, Plovdiv, Bulgaria, 4, 2018, 1, pp. 59-63, ISSN 2367-8127 (CD-ROM), ISSN 23678151 (ON-LINE).

Bogdanova, Margarita. (2017a). Prilozhenie na prostranstveniya analiz v regionalnite izsledvaniya. // Statistikata kato nauka i praktika - traditsii i savremenni izmereniya: Sbornik s dokladi ot nauchnoprakticheska konferentsiya - Svishtov, 20 oktomvri 2017 g., Al Tsenov, 2017, str. 70-76, ISBN: 978954-23-1371-7 (Богданова, Маргарита. Приложение на пространствения анализ в регионалните изследвания. // Статистиката като наука и практика - традиции и съвременни измерения: Сборник с доклади от научно-практическа конференция - Свищов, 20 октомври 2017 г.АИ Ценов, 2017, стр. 70-76, ISBN: 978-954-23-1371-7).

Bogdanova, Margarita. (2016a). Tsentrovete za varhovi postizheniya i za kompetentnost - politiki i podhodi za upravlenie. // Sbornik dokladi ot Godishna universitetska nauchna konferentsiya: Nauchno napravlenie „Sotsialni, stopanski i pravni nauki“- Veliko Tarnovo, 20-21 oktomvri $2016 \mathrm{~g}$. Veliko Tarnovo, NVU - Izd. kompleks, 7, 2016, str. 38-56, ISSN 1314-1937 (Богданова, Маргарита. Центровете за върхови постижения и за компетентност - политики и подходи за управление. // Сборник доклади от Годишна университетска научна конференция: Научно направление "Социални, стопански и правни науки“ - Велико Търново, 20-21 октомври 2016г. Велико Търново, НВУ - Изд. комплекс , 7, 2016, стр. 38-56, ISSN 1314-1937).

Bogdanova, Margarita. (2015a). The stakeholders in the planning process - a network approach to analysis. // Evropeyski praktiki i natsionalni refleksii v planiraneto: Mezhdunarodna yubileyna nauchnoprakticheska konferentsiya: Sbornik s rezyumeta - Svishtov, 24-25 april 2015 g., Al Tsenov, 2015, str. 37-39, ISBN: 978-954-23-1058-7 (Bogdanova, Margarita. The stakeholders in the planning process - a network approach to analysis. // Европейски практики и национални рефрлексии в планирането: Международна юбилейна научно-практическа конференция: Сборник с резюмета - Свищов, 2425 април 2015 г., АИ Ценов, 2015, стр. 37-39, ISBN: 978-954-23-1058-7).

Bogdanova, Margarita. (2011a). Predizvikatelstva pred regionalnoto planirane v Balgariya. // lkonomikata i upravlenieto $v$ XXI vek - resheniya za stabilnost i rastezh: Mezhdunarodna yubileyna nauchna konferentsiya - Svishtov, 8-9. noemvri 2011g.: Sbornik- dokladi, AI Tsenov, 2011, str. 282-286, ISBN: 978-954-23-0679-5 (Богданова, Маргарита. Предизвикателства пред регионалното планиране в 
България. // Икономиката и управлението в XXI век - решения за стабилност и растеж: Международна юбилейна научна конференция - Свищов, 8-9. ноември 2011г.: Сборникдоклади, АИ Ценов, 2011, стр. 282-286, ISBN: 978-954-23-0679-5).

Terziev, V., Banabakova, V., Georgiev, M. (2018i). Modern dimensions of social policies. // International journal scientific papers Vol 23.4 Promoted in Budva, Montenegro 24-27.05.2018, IKM - Skopje, 23, 2018, N 4, pp. 935-944, ISSN 1857-923X (for e-version) ISSN 2545 - 4439 (for printed version).

Terziev, V., Banabakova, V., Georgiev, M. (2018j). Social support as part of social policy. // International journal scientific papers Vol 23.4 Promoted in Budva, Montenegro 24-27.05.2018, IKM - Skopje, 23, 2018, N 4, pp. 973-980, ISSN 1857-923X (for e-version) ISSN 2545 - 4439 (for printed version).

Terziev, V., Banabakova, V., Georgiev, M. (2018k). Structure of the social welfare system in Bulgaria. // International journal scientific papers Vol 23.4 Promoted in Budva, Montenegro 24-27.05.2018, IKM Skopje, 23, 2018, N 4, pp. 1275-1281, ISSN 1857-923X (for e-version) ISSN 2545 - 4439 (for printed version). 